\title{
The Impact of Internet on the Youth Leadership
}

http://doi.org/10.21272/bel.3(3).99-106.2019

\section{Md. Mortuza Ahmmed}

Assistant Professor, Department of Mathematics, American International University - Bangladesh

\section{Zahir Raihan Salim}

Senior Lecturer, College of Business Administration, International University of Business Agriculture and Technology, Bangladesh

\begin{abstract}
In the conditions of digitalization of economy, acceleration of information technologies, automation of industrial processes Internet serves as one of the most powerful and effective tool for successful business activity. The active introduction of communication, information and other services form the prerequisites for the society transition from traditional ways of development to innovations, which are based on the active use of information technologies. One of the areas undergoing digital transformation is the academic life. The use of the Internet for educational purposes is seen as the key to facilitating the learning process, the formation of general and special competences of graduates, their ability to self-discipline, responsibility, autonomy and leadership. The main aim of the research is to analyze the role of information technologies in the formation of leadership qualities of young people, to study the relationship between the students' academic performance and their leadership qualities. The analysis of literary sources and approaches to solving the issue of leadership among the young generation shows that the problem of increasing the academic performance of students in Bangladesh public and private universities through the prism of developing their leadership qualities is of great relevance. The main hypothesis of the work is the connection between the level of academic performance of a student and his/her leadership qualities. The subject of study is students of higher education institutions in Bangladesh. Methodical tools of the study were methods of data analysis and synthesis, regression method, Pearson chi-square test, methods of qualitative and quantitative analysis. Analyses were done using data collected from 609 students of several departments of International University of Business Agriculture and Technology (IUBAT), a private university located in Dhaka, the capital of Bangladesh. The statistical association between academic performance and several explanatory variables was checked. Variables like age, depression, part-time job, internet for movies and/or music, relationship status and hours spend (daily) on the internet for studying were found to impact the academic performance level significantly. The study empirically confirms and theoretically proves that having leadership qualities is one of the key determinants of a student's success, his/her ability to quickly acquire new knowledge and skills. The existence of significant influence of leadership on the level of graduates' employment and the success of their career are substantiated. The findings of this study would help students, teachers and corresponding authority of the institution to comprehend the factors impacting the academic performance of the students and take further actions accordingly.
\end{abstract}

Keywords: leadership, academic performance, CGPA, internet, chi-square test, logistic regression analysis, social networking.

JEL Classification: I2, I29, A22.

Cite as: Ahmmed, Md.M., Salim, Z.R. (2019). The Impact of Internet on the Youth Leadership. Business Ethics and Leadership, 3(3), 99-106. http://doi.org/10.21272/bel.3(3).99-106.2019.

(C) The Authors, 2019. This article is published with open access at Sumy State University.

\section{Introduction}

Internet is nothing but a universally allied network structure. A significant role in the transformation of various aspects of the educational sector was performed by the internet over the last few decades (Choi et al., 2009). The entire higher education system was transformed by technology-driven applications over the years adding new dimensions. As a result, students were obligated to become strong users of the internet in comparison to the general people. The internet was being acknowledged as an incomparable source of information for the students and a device to upgrade their efficiency (Jones, S., 2002; Judd et al., 2010). It was found in research that the use of internet improved the interaction between the students and their 
ISSN (online) - 2520-6311; ISSN (print) - 2520-6761

classmates as well as teachers, increased access to libraries and other relevant databases, and enhanced study hours; resulting in a positive impact on education (Kirschner et al., 2010). Although the positive association was found between the use of the internet and academic performance, it was also noticed that excessive use of the internet had negative consequences on academic performance (Metzger et al., 2003; Suhail et al., 2006). Deterioration in study behavior, drastic collapse in exam grades, being absent in classes and inadequate participation in extracurricular activities were some of the detected academic problems that were caused by too much use of the internet (Akhter, N., 2013). Students' academic performance would be negatively affected due to their obsession with using the internet for social networking sites (Brown et al., 2014).

It is clearly visible from the above-mentioned literature review that use of internet has both positive and negative consequences on the academic performance of the university students. As far academic performance is concerned, Cumulative Grade Point Average (CGPA) is considered as the indicator by most of the researchers around the world (AL-Mutairi, A., 2010). Although a small number of studies about the extent of use of the internet by the university students were conducted in Bangladesh, hardly any of them analyzed the association between academic performance and use of the internet. The objective of the study was to assess the impact of internet use along with other relevant factors on the academic performance of undergraduate students in Bangladesh. Furthermore, the extent of association would also be investigated via odds ratio employing logistic regression analysis.

\section{Literature Review}

This study focuses how on the student's dependency on the internet and how it correlates with academic performance. Past studies show that using the internet has a positive effect on students academic when used in the proper context. One study by Baker and Edwards (2011) showed how online blended learning helped increase student's proper use of social media. The internet can, however, be overused and many students become dependent on the internet, which in turn has led to poor academic performance (Kubey et al., 2001). Furtehr research conducted by Jacobsen and Forste (2011) looked at how social media affects students' academics in a very interesting way. Jacobsen and Forste have created participants that called logbook where they recorded each of the tasks they been assigned. From this information, Jacobsen and Forste were able to determine how much time was actually being spent productively online and how much time was inhibiting students' academics. It was concluded that for every hour a student spent using social media his or her average GPA was decreased by 0.05 to 0.07 points. However, Jacobsen and Forse also found that if the student spent an hour on the internet using it for academic purposes, his or her GPA has a slight positive correlation with grade point average. A study by the American College Health Association reports that $15.1 \%$ of the students stated that their academic performance was impaired by the use of the internet (Englander, Terregrossa, and Wang, 2010). Chang and Perng (2001) carried out research work on "information search habits of graduate students at Tatung University". The purpose of their study was to find out the information requirements and search habits of graduate students at Tatung University in Taipei City, Taiwan. Results of the study show that worldwide web-based databases, electronic journals and search engines are extensively used in the recent past. A study by Jagboro (2003) conducted a case study of internet usage in Nigerian Universities. The study concludes that the use of the internet for academic research would significantly improve through the provision of more access points at departmental and faculty levels. At the University of Maryland, a research conducted by Kelly and Orr (2003) shows that graduate students (69 percent) are more likely to use databases compared to undergraduate students (32 percent). Hanauer et al. (2004) surveyed a diverse community college to assess the use of the internet by the students. The survey showed that although all the students surveyed had free internet access through their college, in total, 81 percent of the students reported to access the most of the college work and 80 percent o email/chat. Chan and Fang (2007) study finds that the internet plays a prominent role among students in Hong Kong. A Majority of the respondents use one to three hours per day. However, in the study conducted by Kaur and Manhas (2008) at the engineering colleges of Punjab and Haryana, India reveals that all the respondents make frequent use of the internet either from their college or workplace. More than 75 percent of the respondents use the internet for education and research purpose. Sampath Kumar and Kumar (2010) showed the students and faculties who participated in the survey are aware of the e-sources and also the internet. Many of the students and faculties learned about the electronic information either by trial and error or through advice of friends.

Luambano and Nawe (2004) conducted on internet use by the students of the University of Dares Salaam. The findings revealed that the students who have access to the internet are not using it effectively. They used it mainly for communication with friends and relatives more than academic purposes. The cause of this 
found to be lack of skills required to use of the internet. The study recommends the provision of more chances of training in internet use. Studies examining the relationship between the use of social networking sites and academic performance have revealed contradictory findings, although the majority has demonstrated negative relations. For example, Kirschner and Karpinski (2010) found that Facebook users, on average, self-reported significantly lower GPAs compared to non-users. In two more studies, Junco (2012a, 2012 b) asked participants to estimate the amount of time spent on Facebook and how often they check Facebook on a point Likert-type scale. The findings similar to those Kirschner and Karpinski (2010), showed that the amount of time spent on Facebook and checking Facebook more frequently were negative and significant predictors of time spent preparing for the class and GPA Junco (2012a, 2012b). Surprisingly, the relationship cell phone use and academic performance among college students have received less attention. Using subjective ratings, Braguglia (2008) found that 23.7 percent of the business undergraduate selfreported that they felt their call phone interfered with classroom learning sometimes, often or always. Further 78.1 percent of the sample indicated that they felt their cell phone interfered with classroom learning sometimes, often, or always. Using self-reported GPAs, Wentworth and Middleton (2014), in contrast, reported a non-significant relation between cell phone usage and academic performance. Besides the researchers also found that online media usage for education also helps students in improving their academic achievement (Shahibi, M. S., \& Rusli, K. N., 2017). According to Emeka, U. J., \& Nyeche, O. S. (2016), the university should embark on information literacy/sensitization programs for students in order to effectively harness the various web-based electronic resources it is subscribed to.

\section{Methodology}

Primary data were gathered for the study from undergraduate students of Fall semester 2018 of International University of Business Agriculture and Technology (IUBAT). A pre-coded self-guided questionnaire was developed at the outset for data collection purpose. It was then confirmed after being pretested on a small sample of 40 students encompassing different programs. There are around 10000 students altogether under various colleges in IUBAT. An estimated sample size of 609students was interrogated for the study considering a $4 \%$ margin of error (3.85\% to be exact) at $95 \%$ confidence interval. The subject of nonresponse rate was not taken into attention since the survey was organized under the straight direction of respective course teachers within the classrooms. Stratified sampling technique was employed where each of the class-sections under different colleges was considered as a stratum. Hence, the ultimate sample of 609 students covered all the departments under different colleges, namely, College of Business Administration, College of Engineering and Technology, College of Arts and Sciences, College of Agricultural Sciences, College of Tourism and Hospitality Management and College of Nursing.

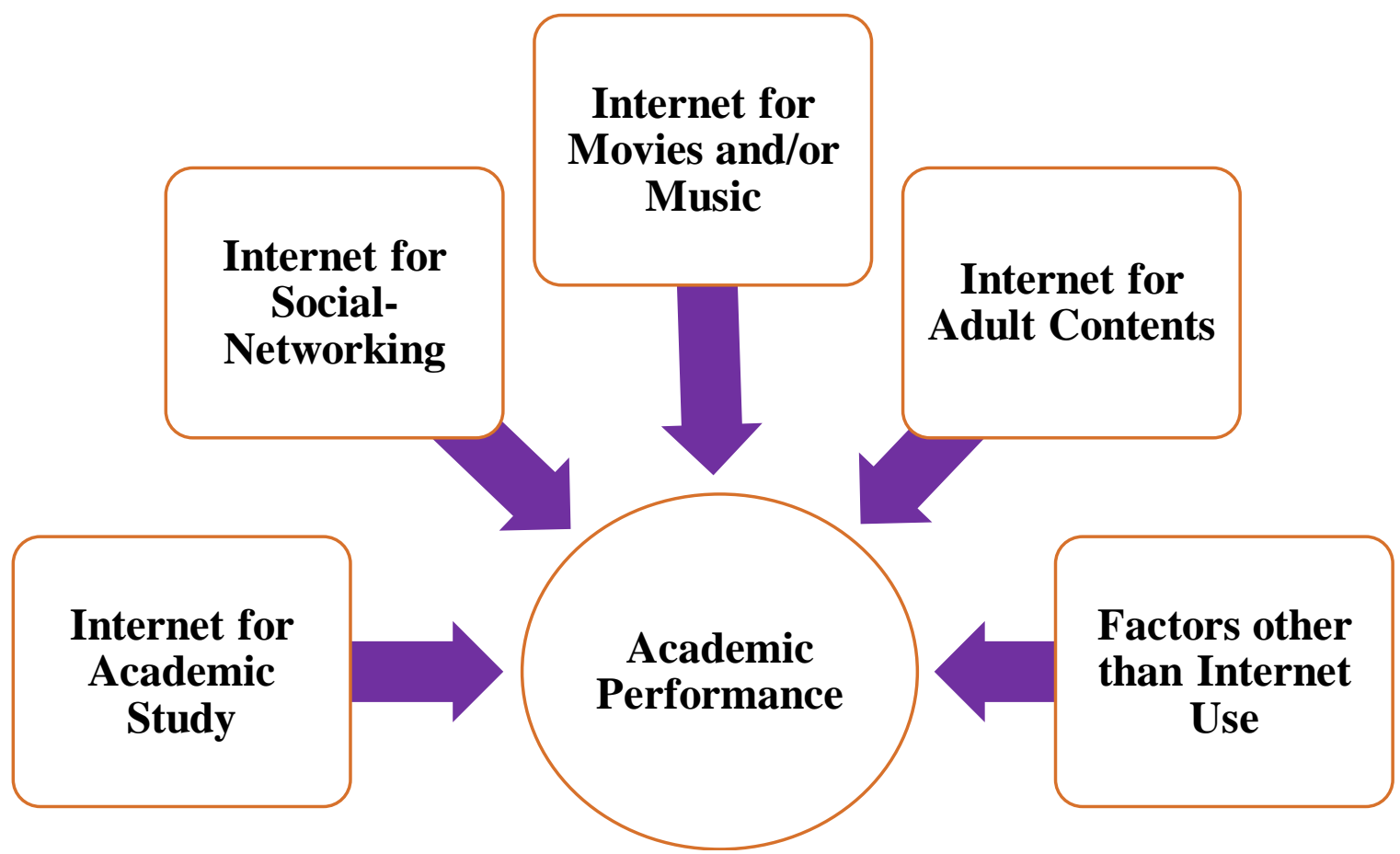

Figure 1. Conceptual framework

Source: Md. Mortuza Ahmmed, Zahir Raihan Salim (2018). Determinants of Academic Performance of Undergraduate Students in Private Universities in Bangladesh: A Case Study. Global Journal of Human-Social Science, 18(11). 
Several independent variables related to internet use were considered that were categorized as the internet for studying, internet for social-networking, internet for movies and/or music and internet for adult contents. Also, factors other than internet use like gender, age, residence, class attendance, depression, part-time job, relationship status, etc. were taken into consideration. The dependent variable for the study was an academic performance which is also dichotomous, where CGPA $\geq 3.00$ was coded as 1 and CGPA $<3.00$ was coded as 0 . The association between academic performance and all the above-mentioned independent variables were checked by applying the chi-square test, where $p$-value $\leq 0.05$ indicated a significant association.

Finally, the logistic regression model was fitted among academic performance and the independent variables that showed significant association with it. Logistic regression is a widely applied regression analysis when the dependent variable is dichotomous. No assumption regarding the distributions of the independent variables is needed. It delivers an estimated value for the strength of the association adjusting for other variables. The exponential of the coefficients represents odd ratios (OR) for the given variable. The analysis was performed using SPSS version 20.0. The dependent variable was dichotomous given value 1 if the delivery was attended by trained medical personnel and given value 0 otherwise. The model was fitted as:

$E(y)=\frac{e^{\beta X}}{1+e^{\beta X}}$,

$\beta=\left[\beta_{0}, \beta_{1}, \beta_{2}, \ldots \ldots, \beta_{k}\right]$,

$X=\left[x_{1}, x_{2}, x_{3}, \ldots \ldots, x_{k}\right]^{\prime}$

here, $y=$ dependent variable $=$ academic performance,

$x_{i}=$ corresponding independent variables,

$\beta_{i}=$ parameters of the model.

\section{Results and Discussion}

The background characteristics of the respondents are shown in Table 1. Most of the students (45.3\%) were from engineering departments. The number of male students was approximately 1.55 times more than its female counterpart indicating the supremacy of male students at tertiary level education. A large proportion of the students (61.6\%) belonged to the age group of above 20 years. Most of them (71.6\%) came from urban areas which were expected since education in private universities is an expensive deal and is out of reach in case of most of the rural people. One of the positive aspects of the respondents was their class attendance. Around $86 \%$ of them attended their respective classes regularly. Close to half of the students (46.6\%) were suffering from depression which indicated an alarming psychological condition of them. A relatively much higher proportion of students $(78.2 \%)$ were involved with a part-time job. Approximately two-thirds of the students $(66.7 \%)$ were single as far as their relationship status was concerned. A large portion of the students $(67.8 \%)$ used the internet for their study purpose. Almost identical results were found regarding the use of the internet for social-networking (61.3\%), for movies and/or music $(72.8 \%)$, for gaming $(60.3 \%)$. However, the opposite picture was found regarding the use of the internet for adult contents (35.1\%). Almost $71 \%$ of the students used to spend up to 3 hours over the internet for academic study daily. Half of the students used to spend at least 3 hours over the internet for social-networking daily. A relatively much bigger proportion of them $(87.4 \%)$ used to spend up to 3 hours over the internet for movies and/or music. A huge portion of the students $(88.7 \%)$ used to spend at least 3 hours over the internet for adult contents. Academic performance of almost two-third of them (63.5\%) was at a satisfactory level. 
Table 1. Distribution of respondents by background characteristics

\begin{tabular}{|c|c|c|c|}
\hline & & Frequency & Percentage \\
\hline \multirow{4}{*}{ Department } & Business & 276 & 45.3 \\
\hline & Engineering & 227 & 37.3 \\
\hline & Others & 106 & 17.4 \\
\hline & Total & 609 & 100.0 \\
\hline \multirow{3}{*}{ Gender } & Male & 370 & 60.8 \\
\hline & Female & 239 & 39.2 \\
\hline & Total & 609 & 100.0 \\
\hline \multirow{3}{*}{ Age } & At most 20 & 234 & 38.4 \\
\hline & Above 20 & 375 & 61.6 \\
\hline & Total & 609 & 100.0 \\
\hline \multirow{3}{*}{ Residence } & Urban & 436 & 71.6 \\
\hline & Rural & 173 & 28.4 \\
\hline & Total & 609 & 100.0 \\
\hline \multirow{3}{*}{ Class Attendance } & Regular & 524 & 86.0 \\
\hline & Irregular & 85 & 14.0 \\
\hline & Total & 609 & 100.0 \\
\hline \multirow{3}{*}{ Depression } & No & 325 & 53.4 \\
\hline & Yes & 284 & 46.6 \\
\hline & Total & 609 & 100.0 \\
\hline \multirow{3}{*}{ Part-time Job } & Yes & 476 & 78.2 \\
\hline & No & 133 & 21.8 \\
\hline & Total & 609 & 100.0 \\
\hline \multirow{3}{*}{ Relationship status } & Single & 406 & 66.7 \\
\hline & In a relationship & 203 & 33.3 \\
\hline & Total & 609 & 100.0 \\
\hline \multirow{3}{*}{ Internet for studying } & Yes & 413 & 67.8 \\
\hline & No & 196 & 32.2 \\
\hline & Total & 609 & 100.0 \\
\hline \multirow{3}{*}{ Internet for social-networking } & Yes & 373 & 61.3 \\
\hline & No & 236 & 38.7 \\
\hline & Total & 609 & 100.0 \\
\hline \multirow{3}{*}{ Internet for movies and/or music } & Yes & 443 & 72.8 \\
\hline & No & 166 & 27.2 \\
\hline & Total & 609 & 100.0 \\
\hline \multirow{3}{*}{ Internet for gaming } & Yes & 367 & 60.3 \\
\hline & No & 242 & 39.7 \\
\hline & Total & 609 & 100.0 \\
\hline \multirow{3}{*}{ Internet for adult contents } & Yes & 214 & 35.1 \\
\hline & No & 395 & 64.9 \\
\hline & Total & 609 & 100.0 \\
\hline \multirow{3}{*}{$\begin{array}{l}\text { Hours spend (daily) on the internet for } \\
\text { studying }\end{array}$} & At most 3 hours & 430 & 70.6 \\
\hline & At least 3 hours & 179 & 29.4 \\
\hline & Total & 609 & 100.0 \\
\hline \multirow{3}{*}{$\begin{array}{l}\text { Hours spend (daily) on the internet for } \\
\text { social-networking }\end{array}$} & At most 3 hours & 304 & 49.9 \\
\hline & At least 3 hours & 305 & 50.1 \\
\hline & Total & 609 & 100.0 \\
\hline \multirow{3}{*}{$\begin{array}{l}\text { Hours spend (daily) on the internet for } \\
\text { movies and/or music }\end{array}$} & At most 3 hours & 532 & 87.4 \\
\hline & At least 3 hours & 77 & 12.6 \\
\hline & Total & 609 & 100.0 \\
\hline \multirow{3}{*}{$\begin{array}{l}\text { Hours spend (daily) on the internet for } \\
\text { gaming }\end{array}$} & At most 3 hours & 270 & 44.3 \\
\hline & At least 3 hours & 339 & 55.7 \\
\hline & Total & 609 & 100.0 \\
\hline \multirow{3}{*}{$\begin{array}{l}\text { Hours spend (daily) on the internet for adult } \\
\text { contents }\end{array}$} & At most 3 hours & 69 & 11.3 \\
\hline & At least 3 hours & 540 & 88.7 \\
\hline & Total & 609 & 100.0 \\
\hline & Satisfactory & 361 & 59.3 \\
\hline Academic Performance & Not Satisfactory & 248 & 40.7 \\
\hline & Total & 609 & 100.0 \\
\hline
\end{tabular}

Source: Randomly selected sample of 609 students of IUBAT

The analytical results of chi-square tests are shown in Table 2. Some of the explanatory variables like age, depression, part-time job, internet for movies and/or music, relationship status and hours spend (daily) on the internet for studying were found to possess significant association with academic performance as shown in Table 2 (p-value $\leq 0.05$ ). 
Table 2. Distribution of respondents by academic performance and explanatory variables

\begin{tabular}{|c|c|c|c|c|c|}
\hline & \multicolumn{2}{|c|}{ Academic Performance } & \multirow[b]{2}{*}{ Total } & \multirow[b]{2}{*}{ Significance } \\
\hline & & Satisfactory & Not Satisfactory & & \\
\hline \multirow{4}{*}{ Department } & Business & 172 & 104 & 276 & \multirow{4}{*}{$\begin{array}{c}\chi^{2}=3.888 \\
\text { p-value }=0.143\end{array}$} \\
\hline & Engineering & 123 & 104 & 227 & \\
\hline & Others & 66 & 40 & 106 & \\
\hline & Total & 361 & 248 & 609 & \\
\hline \multirow{3}{*}{ Gender } & Male & 214 & 156 & 370 & \multirow{3}{*}{$\begin{array}{c}\chi^{2}=0.81 \\
\text { p-value }=0.208\end{array}$} \\
\hline & Female & 147 & 92 & 239 & \\
\hline & Total & 361 & 248 & 609 & \\
\hline \multirow{3}{*}{ Age } & At most 20 & 153 & 81 & 234 & \multirow{3}{*}{$\begin{array}{c}\chi^{2}=5.872 \\
\text { p-value }=0.009\end{array}$} \\
\hline & Above 20 & 208 & 167 & 375 & \\
\hline & Total & 361 & 248 & 609 & \\
\hline \multirow{3}{*}{ Residence } & Urban & 261 & 175 & 436 & \multirow{3}{*}{$\begin{array}{c}\chi^{2}=0.218 \\
\text { p-value }=0.353\end{array}$} \\
\hline & Rural & 100 & 73 & 173 & \\
\hline & Total & 361 & 248 & 609 & \\
\hline \multirow{3}{*}{ Class Attendance } & Regular & 308 & 216 & 524 & \multirow{3}{*}{$\begin{array}{c}\chi^{2}=0.981 \\
\text { p-value }=0.612\end{array}$} \\
\hline & Irregular & 53 & 32 & 85 & \\
\hline & Total & 361 & 248 & 609 & \\
\hline \multirow{3}{*}{ Depression } & No & 216 & 109 & 325 & \multirow{3}{*}{$\begin{array}{c}\chi^{2}=14.90 \\
\text { p-value }=0.000\end{array}$} \\
\hline & Yes & 145 & 139 & 284 & \\
\hline & Total & 361 & 248 & 609 & \\
\hline \multirow{3}{*}{ Part-time Job } & Yes & 304 & 172 & 426 & \multirow{3}{*}{$\begin{array}{c}\chi^{2}=23.788 \\
\text { p-value }=0.000\end{array}$} \\
\hline & No & 57 & 76 & 133 & \\
\hline & Total & 361 & 248 & 609 & \\
\hline & Single & 220 & 186 & 406 & $\chi^{2}=13.482$ \\
\hline Relationship status & In a relationship & 141 & 62 & 203 & $\mathrm{p}$-value $=0.001$ \\
\hline & Total & 361 & 248 & 609 & \\
\hline & Yes & 248 & 165 & 413 & $\chi^{2}=0.387$ \\
\hline Internet for studying & No & 113 & 83 & 196 & $\mathrm{p}$-value $=0.824$ \\
\hline & Total & 361 & 248 & 609 & \\
\hline & Yes & 212 & 161 & 373 & $\chi^{2}=2.700$ \\
\hline Internet for social-networking & No & 149 & 87 & 236 & p-value $=0.440$ \\
\hline & Total & 361 & 248 & 609 & \\
\hline & Yes & 257 & 186 & 443 & $\chi^{2}=12.377$ \\
\hline Internet for movies and/or & No & 104 & 62 & 166 & p-value $=0.006$ \\
\hline music & Total & 361 & 248 & 609 & \\
\hline & Yes & 214 & 153 & 367 & $\chi^{2}=1.097$ \\
\hline Internet for gaming & No & 147 & 95 & 242 & p-value $=0.778$ \\
\hline & Total & 361 & 248 & 609 & \\
\hline & Yes & 138 & 76 & 214 & $\chi^{2}=4.279$ \\
\hline Internet for adult contents & No & 223 & 172 & 395 & $\mathrm{p}$-value $=0.233$ \\
\hline & Total & 361 & 248 & 609 & \\
\hline Hours spend (daily) on the & At most 3 hours & 241 & 189 & 430 & $\chi^{2}=6.837$ \\
\hline internet for studying & At least 3 hours & 120 & 59 & 179 & p-value $=0.017$ \\
\hline & Total & 361 & 248 & 609 & \\
\hline Hours spend (daily) on the & At most 3 hours & 185 & 119 & 304 & $\chi^{2}=0.668$ \\
\hline internet for social-networking & At least 3 hours & 176 & 129 & 305 & $\mathrm{p}$-value $=0.716$ \\
\hline & Total & 361 & 248 & 609 & \\
\hline Hours spend (daily) on the & At most 3 hours & 310 & 222 & 532 & $\chi^{2}=1.767$ \\
\hline internet for movies and/or & At least 3 hours & 51 & 26 & 77 & $\mathrm{p}$-value $=0.113$ \\
\hline music & Total & 361 & 248 & 609 & \\
\hline Hours spend (daily) on the & At most 3 hours & 165 & 105 & 270 & $\chi^{2}=0.676$ \\
\hline internet for gaming & At least 3 hours & 196 & 143 & 339 & $\mathrm{p}$-value $=0.230$ \\
\hline & Total & 361 & 248 & 609 & \\
\hline Hours spend (daily) on the & At most 3 hours & 32 & 37 & 69 & $\chi^{2}=27.22$ \\
\hline internet for adult contents & At least 3 hours & 329 & 211 & 540 & $\mathrm{p}$-value $=0.285$ \\
\hline & Total & 361 & 248 & 609 & \\
\hline
\end{tabular}

Source: Randomly selected sample of 609 students of IUBAT

The logistic regression results are shown in Table 3. Other than the internet for movies and/or music, the remaining variables showing significant association in Table 2 are still showing significant association with academic performance in Table 3 . 
Business Ethics and Leadership, Volume 3, Issue 3, 2019 ISSN (online) - 2520-6311; ISSN (print) - 2520-6761

Table 3. Logistic regression results

\begin{tabular}{|c|c|c|c|c|c|c|c|}
\hline & \multirow[b]{2}{*}{$\boldsymbol{\beta}$} & \multirow[b]{2}{*}{ Wald } & \multirow[b]{2}{*}{ Significance } & \multirow{2}{*}{$\begin{array}{c}e^{\beta} \\
(\mathbf{O R})\end{array}$} & \multicolumn{2}{|c|}{ 95\% C.I. for OR } \\
\hline & & & & & & Lower & Upper \\
\hline Age & $\begin{array}{l}\text { At most } 20(\mathrm{RC}) \\
\text { Above } 20\end{array}$ & $\begin{array}{c}- \\
0.300 \\
\end{array}$ & $\begin{array}{c}- \\
2.639 \\
\end{array}$ & 0.015 & $\begin{array}{c}- \\
1.349\end{array}$ & $\begin{array}{c}- \\
0.940\end{array}$ & $\begin{array}{c}- \\
1.937 \\
\end{array}$ \\
\hline Relationship status & $\begin{array}{l}\text { Single }(\mathrm{RC}) \\
\text { In a relationship }\end{array}$ & $\begin{array}{c}- \\
-0.406\end{array}$ & $\begin{array}{c}- \\
5.912\end{array}$ & 0.000 & $\begin{array}{c}- \\
0.666\end{array}$ & $\begin{array}{c}- \\
0.480\end{array}$ & $\begin{array}{c}- \\
0.924\end{array}$ \\
\hline $\begin{array}{l}\text { Internet for movies and/or } \\
\text { music }\end{array}$ & $\begin{array}{l}\text { Yes }(\mathrm{RC}) \\
\text { No }\end{array}$ & $\begin{array}{c}- \\
-0.137 \\
\end{array}$ & $\begin{array}{c}- \\
2.588 \\
\end{array}$ & 0.388 & $\begin{array}{c}- \\
0.872\end{array}$ & $\begin{array}{c}- \\
0.737\end{array}$ & $\begin{array}{c}- \\
1.030\end{array}$ \\
\hline $\begin{array}{l}\text { Hours spend (daily) on } \\
\text { internet for studying }\end{array}$ & $\begin{array}{l}\text { At most } 3 \text { hours }(\mathrm{RC}) \\
\text { At least } 3 \text { hours } \\
\end{array}$ & $\overline{-}$ & $\begin{array}{c}- \\
3.550 \\
\end{array}$ & 0.031 & $\begin{array}{c}- \\
1.162 \\
\end{array}$ & $\begin{array}{c}- \\
0.994 \\
\end{array}$ & $\begin{array}{c}- \\
1.359 \\
\end{array}$ \\
\hline Part-time job & $\begin{array}{l}\text { Yes (RC) } \\
\text { No }\end{array}$ & $\begin{array}{c}- \\
1.095\end{array}$ & $\begin{array}{c}- \\
27.580\end{array}$ & 0.000 & $\begin{array}{c}- \\
2.990\end{array}$ & $\begin{array}{c}- \\
1.987\end{array}$ & $\begin{array}{c}- \\
4.500\end{array}$ \\
\hline Depression & $\begin{array}{l}\text { Yes (RC) } \\
\text { No }\end{array}$ & $\begin{array}{c}- \\
0.509\end{array}$ & $\begin{array}{c}- \\
8.475\end{array}$ & 0.000 & $\begin{array}{c}- \\
1.663\end{array}$ & $\begin{array}{c}- \\
1.181\end{array}$ & $\begin{array}{c}- \\
2.343\end{array}$ \\
\hline
\end{tabular}

C.I. $=$ Confidence Interval, $\mathrm{OR}=$ Odds Ratio, $\mathrm{RC}=$ Reference Category

Source: Randomly selected sample of 609 students of IUBAT

Academic performance of students above 20 years was 1.349 times better than those whose age was at most 20. Students become matured over time and that positively impacts their academic performance. Students suffering through depression were less likely to perform better than those without depression. It is also reflected by our findings in Table 3. Students without depression were 1.663 times more likely to perform better academic result than their depressed counterparts. As expected, students engaged in a relationship were found to be less likely $(\mathrm{OR}=0.666)$ to perform better than single ones. Students undertaking no parttime job were 1.987 times more likely to perform better than those undertaking the part-time job. Extra time being spent in the part-time job might have affected their academic result as those involved in the part-time job had less time in their hands to input in study purpose.

\section{Conclusion}

There were a few limitations of the study. Firstly, overall students in the university are being reflected in the sample as PPS (probability proportional to size) method was applied for data collection. As a major portion of the students of IUBAT belongs to engineering departments, so it was expected that most of the respondents will belong to it. Secondly, as far as age group is concerned, students get admitted at universities in Bangladesh after passing their HSC exam which usually happens around 18 years of age. We collected data from students who at least passed 2 to 3 semesters. That is why a large proportion of the students belonged to the age group of above 20 years.

The findings of this study will have crucial strategy implications to the management of private universities in Bangladesh. Not only the students but also their families will realize which factors would have a significant impact on students' academic success. The study will also help to undertake proper actions by Institutional Quality Assurance Cell (IQAC) in the universities as well. The number of private universities will continue its ever-increasing trend in the upcoming future, so now is the time to take necessary steps to ensure the quality of education at this level. It is the huge amount of tuition fee being paid by the students in the private universities that ultimately runs the life of the institutions. So, their academic performance level must be taken care of seriously. Bangladesh Telecommunication Regulatory Commission (BTRC) has recently started blocking gateways of thousands of websites, which are supposed to have a severe negative impact on the young generation of the country. They should regularly perform this to ensure the safe use of the internet by the probable future leaders of the country.

\section{References}

1. Akhter, N. (2013). Relationship between Internet Addiction and Academic Performance among University Undergraduates. Journal of Science and Technology Education Research, 8(19), 1793-1796.

2. AL-Mutairi, A. (2010). Factors affecting business students' performance in Arab open university: Case of Kuwait. International Journal of Business and Management, 6(5), 146-155.

3. Baker, C., \& Edwards, J. T. (2011). A holistic approach for establishing social presence in online courses \& programs. The International HETL Review, 1(7). Retrieved from http://hetl.org/2011/08/17/socialpresence-in-online-courses/. 
Business Ethics and Leadership, Volume 3, Issue 3, 2019

ISSN (online) - 2520-6311; ISSN (print) - 2520-6761

4. Brown et al. (2014). The Influence of Internet Usage on Academic Performance and Face-to Face Communication. Journal of Psychology and Behavioral Science, 2(2), 163-186.

5. Chan, K. and Fang, W. (2007). Use of the Internet and traditional media among young people. Young Consumers: Insight and Ideas for Responsible Marketers, 8(4), 244-256.

6. Chang, N.C. and Perng, J.H. (2001). Information search habits of graduate students at Tatung University. International Information \& Library Review, 33(4), 341-346.

7. Choi et al. (2009). Internet overuse and excessive daytime sleepiness in adolescents. Psychiatry and Clinical Neurosciences, 63, 455-462.

8. Emeka, U. J., \& Nyeche, O. S. (2016). Impact of Internet Usage on the Academic Performance of Undergraduates Students: A case study of the University of Abuja, Nigeria. International Journal of Scientific \& Engineering Research, 7(10), 1018-1029.

9. Englander, F., Terregrossa, R. A., \& Wang, Z. (2010). Internet use among college students: Tool or toy? Educational Re-view, 62(1), 85-96. doi:10.1080/00131910903519793.

10.Hanauer, D., Dibble, E., Fortin, J. and Col, N.F. (2004). Internet use among community college students: implications in designing healthcare interventions. Journal of American College Health, 52(5), $197-202$.

11.Jacobsen, W., \& Forste, R. (2011). The wired generation: Academic and social outcomes of electronic media use among university students. Cyber psychology, Behavior, and Social Networking. 14(5). doi: 10.1089/cyber.2010.0135.

12.Jagboro, K.O. (2003). A study of Internet usage in Nigerian universities: a case study of Obafemi Awolowo University, Ile-Ife, Nigeria. First Monday, 8(2). Available at: http:// firstmonday.orgissues/issue82/jagboro/index.html (accessed February 10, 2019).

13.Jones, S. (2002). The Internet goes to college: How students are living in the future with today's technology. Research Report, Pew Research Center.

14.Judd et al. (2010). A five-year study of on-campus internet use by undergraduate biomedical students. Computers \& Education, 55, 1564-1571.

15.Junco, R. (2012a). The relationship between frequency of Facebook use, participation in Facebook activities, and student engagement. Computers \& Education, 58, 162-171. doi: 10.1016/j.compedu.2011.08.004.

16.Junco, R. (2012b). Too much face and not enough books: The relationship between multiple indices of Facebook use and academic performance. Computers in Human Behavior, 28, 187-198. doi:10.1016/j chb.2011.08.026.

17.Kaur, A. and Manhas, R. (2008). Use of Internet services and resources in the engineering colleges of Punjab and Haryana (India): a study. The International Information \& Library Review, 40(1), 10-20.

18.Kelley, K.B. and Orr, G.J. (2003). Trends in distant use of electronic resources: a survey. College and Research Libraries, 64(3), 176-191.

19.Kirschner et al. (2010). Running head: Facebook and academic performance. Computers in Human Behavior, 26, 1237-1245.

20.Kirschner, P. A., \& Karpinski, A. C. (2010). Facebook and academic performance. Computers in Human Behavior, 26, 1237-1245. doi:10.1016/j.chb.2010.03.024.

21.Kubey, R. W., Lavin, M. J., \& Barows, J. R. (2001). Internet use and collegiate academic performance decrements: Early findings. Journal of Communication, 51(2), 366-382. doi:10.1111/j.14602466.2001.tb02885.x.

22.Luambano, I. and Nawe, J. (2004). Internet use by students of the University of Dares Salaam. Library Hi Tech News, 21(10), 13-17.

23. Metzger et al. (2003). College students web use, perceptions of information credibility and verification behavior. Computers and Education, 41, 271-290.

24.Sampath Kumar, B.T. and Kumar, G.T. (2010). Perception and usage of e-resources and the Internet by Indian academics. The Electronic Library, 28(1), 137-156.

25.Shahibi, M. S., \& Rusli, K. N. (2017). The Influence of Internet Usage on Student's Academic Performance. International Journal of Academic Research in Business and Social Sciences, 7(8), 873-887.

26. Suhail et al. (2006). Effects of excessive internet use on undergraduate students in Pakistan. Cyber Psychology and Behavior, 9(3), 297-307.

27.Wentworth, D. K., \& Middleton, J. H. (2014). Technology use and academic performance. Computers \& Education, 78, 306-311. doi:10.1016/j.compedu.2014.06.012. 